\title{
Review
}

\section{The use of marine-derived bioactive compounds as potential hepatoprotective agents}

\author{
Dileep G NAIR ${ }^{1, *}$, Ralf WEISKIRCHEN ${ }^{2}$, Salma K AI-MUSHARAFI ${ }^{1}$ \\ ${ }^{1}$ Department of Applied Biotechnology, Sur College of Applied Sciences, Ministry of Higher Education, Sur, Sultanate of Oman; \\ ${ }^{2}$ Institute of Clinical Chemistry and Pathobiochemistry, RWTH University Hospital Aachen, Aachen, Germany
}

\begin{abstract}
The marine environment may be explored as a rich source for novel drugs. A number of marine-derived compounds have been isolated and identified, and their therapeutic effects and pharmacological profiles are characterized. In the present review, we highlight the recent studies using marine compounds as potential hepatoprotective agents for the treatment of liver fibrotic diseases and discuss the proposed mechanisms of their activities. In addition, we discuss the significance of similar studies in Oman, where the rich marine life provides a potential for the isolation of novel natural, bioactive products that display therapeutic effects on liver diseases.
\end{abstract}

Keywords: liver fibrosis; hepatoprotective agent; marine compound; Scytonemin; Pacifenol; Epitaondiol; Stypotriol; Contignasterol; Xestobergsterol; Clathriol; Hymenialdisine; Hyrtiosal

Acta Pharmacologica Sinica (2015) 36: 158-170; doi: 10.1038/aps.2014.114; published online 15 Dec 2014

\section{Introduction}

The prevalence of liver diseases, including chronic hepatitis and cirrhosis, necessitates effective and cost-efficient treatments. The marine environment may be explored as a rich source for novel antifibrotic drugs. A number of marinederived compounds are shown to prevent ROS formation, possess anti-inflammatory activities, interfere with the TGF- $\beta$ and PDGF- $\beta$ pathways, or affect the NF- $\mathrm{kB}$ pathway. Furthermore, most of the compounds have negligible immunogenicity and side effects. This review provides an overview of the recent studies using marine compounds as potential hepatoprotective agents for the treatment of fibrotic liver diseases and discusses the proposed mechanisms of their activities.

\section{Liver inflammation, fibrosis, and cirrhosis}

Although liver disease is caused by a variety of different etiologies, such as alcohol abuse, viral infections (eg, hepatitis B or C virus), and metabolic syndrome, resulting in nonalcoholic steatohepatitis, autoimmune diseases, cholestasis, genetic metabolic diseases, drug abuse, or toxin intoxication, the pathogenesis of chronic liver disease is relatively uniform. An inflammatory process is initiated in which the parenchymal cells (ie, hepatocytes) are affected by necrosis or apoptosis. This cellular damage leads to hepatic release of molecular

\footnotetext{
* To whom correspondence should be addressed.

E-mail dileep.sur@cas.edu.om

Received 2014-05-06 Accepted 2014-09-26
}

mediators, infiltration of immune cells, and inflammationinduced activation of normally quiescent hepatic stellate cells (HSC) and their transdifferentiation into myofibroblasts (MFB) (Figure 1). HSC (formerly also known as vitamin A storage cells, Ito cells, or fat storage cells) are pericytes of the liver, which together with sinusoidal endothelial cells (SEC) and Kupffer cells (KC) line the hepatic sinusoid ${ }^{[1,2]}$. As well as storing vitamin $\mathrm{A}$, this cell type is important for the intrahepatic presentation of antigens ${ }^{[3]}$, the removal of apoptotic parenchymal cells, the secretion of important apolipoproteins and growth factors, and the control of blood flow, in addition to acting as a progenitor for damaged hepatocytes and endothelial cells ${ }^{[4]}$. In liver fibrosis, HSC play a central role because they are stimulated to leave their quiescent phenotype and transform into extracellular matrix (ECM) producing cells (ie, MFB). Signs of their activation include the loss of their vitamin A store, the expression of typical activation markers (eg, a-smooth muscle actin), the acquisition of contractile properties, and an increase in the synthesis of a variety of pro-inflammatory cytokines, chemokines, as well as other growth factors. All of these mediators initiate a complex network of autocrine and paracrine activities resulting in an increased net synthesis and intrahepatic deposition of ECM components, such as collagens. The quantities of cells capable of forming ECM are further increased by fibrocytes (immigrating from the bone marrow), portal fibroblasts and potentially by cells dedifferentiated by an epithelial-mesenchymal transition in which hepatocytes acquire MFB-like properties via a well programmed 
A

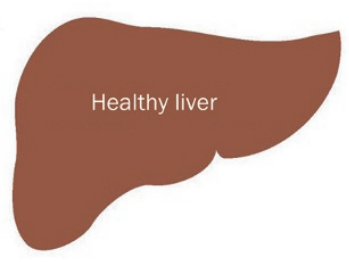

Alcohol, Hepatitis Metabolic obstructions

Hereditary disorders Intoxication, Drugs

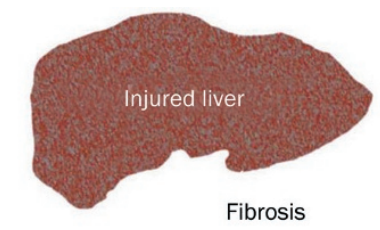

B

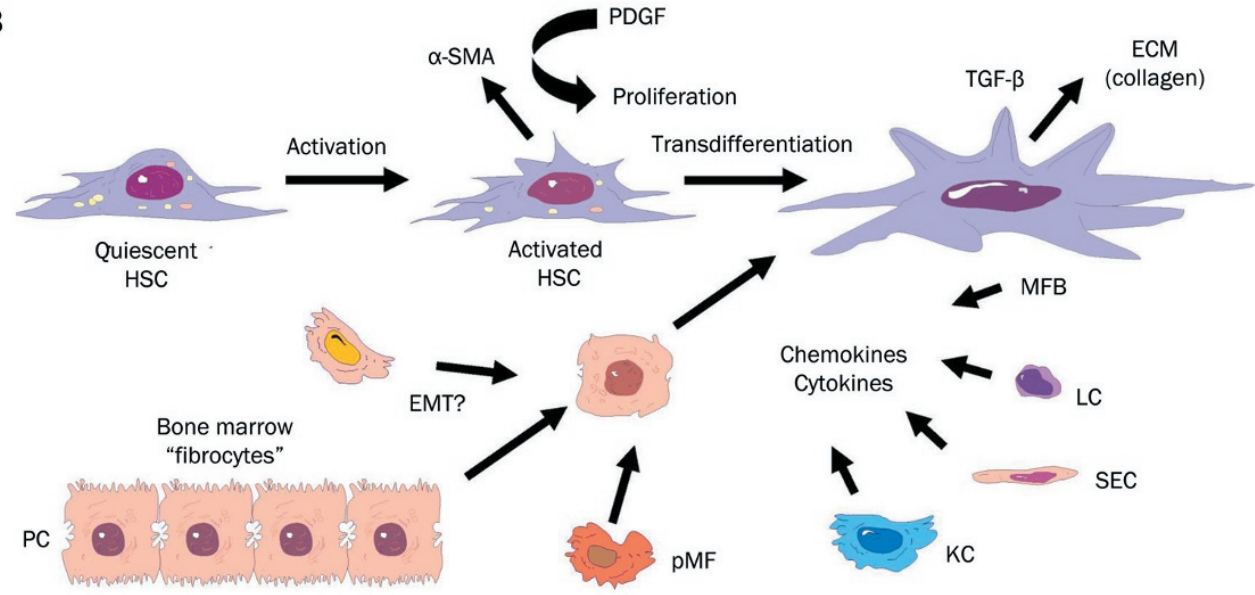

Figure 1. Pathogenesis of hepatic fibrosis. (A) The healthy liver is prompted by various triggers (extensive alcohol abuse, hepatitis infection, metabolic disorders, genetic diseases, intoxication, and drug consumption) to undergo hepatic fibrogenesis resulting in an injured, fibrotic liver; (B) At the cellular level, hepatic fibrogenesis is a complex process. Toxic triggers in the liver promote the activation of quiescent hepatic stellate cells (HSC) that become positive for $\alpha$-smooth muscle actin ( $\alpha$-SMA), start to proliferate and transdifferentiate into contractile myofibroblasts that have the capacity to synthesize large quantities of extracellular matrix (ECM). Hepatic fibrogenesis is markedly stimulated by platelet-derived growth factor (PDGF) and TGF- $\beta$ that control collagen expression and cellular proliferation. The events are further triggered by other chemokines and cytokines that are secreted by liver residential cells (KC, Kupffer cells; SEC, sinusoidal endothelial cells) or infiltrating leukocyte (LC) subsets. Moreover, ECM synthesis is further driven by portal (myo)fibroblast (pMF) and bone marrow derived fibrocytes. In addition, whether hepatocytes can transit into cells that are capable of ECM synthesis in a process that is commonly known as epithelial-to-mesenchymal-transition (EMT), is under debate.

transition process ${ }^{[5]}$. All of these alterations are favored by the soluble mediators that are released by the resident macrophages of the liver (ie, KC), SEC, or infiltrating lymphocytes. The modes of action of these molecular messengers are quite different. Transforming growth factor beta (TGF- $\beta$ ), for example, is a pleiotropic effector molecule that triggers the expression of several ECM proteins, while reducing its degradation by inhibiting the so-called matrix metalloproteinases and the synthesis of specific inhibitors of these enzymes. TGF- $\beta$ further induces the apoptosis of hepatocytes and inhibits cell proliferation and thus is essential to rebuild damaged liver tissue. Other cytokines, such as the platelet-derived growth factor (PDGF)- $\beta$, drive the proliferation of activated HSC and thus increase the quantities of cells able to synthesize ECM components ${ }^{[6]}$. A large set of other cytokines and chemokines are also released by the invaded cells and influence HSC biology through propagating the inflammatory process and thus the fatal sequence of organ damage ${ }^{[1,7]}$. The result is liver fibrosis, which is mainly characterized by the intrahepatic deposition of collagen fibers resulting in liver malfunction, the abolition of liver architecture, or even the impairment of liver function. Fibrosis causes a lack of synthesis of important hepatic biomolecules (transport proteins, coagulation factors, and globulins), a deficiency in the detoxification of endogenous (bilirubin, ammonia, and steroid hormones) and exogenous (drugs) toxic substances, and deficiencies in the regulation of vitamin and trace element metabolism. At this stage, the liver is unable to restore the damaged parenchymal tissue, while the connective tissue is simultaneously increased, resulting in the destruction of the lobular structure. This final phase is called cirrhosis and is regarded as an optional precancerous lesion from which hepatocellular carcinoma may develop.

\section{Currently available drugs/treatments, their efficiency and drawbacks}

The molecular characterization of the processes involved in liver fibrosis, including liver inflammation and tissue remodeling, resulted in the development of diverse therapeutic means to prevent or cure the disease. In this regard, two major available approaches have been discussed for several decades ${ }^{[8]}$. The simplest treatment is the removal of the causal agent, which is a major therapy for liver inflammatory diseases except autoimmune diseases, where the full removal of immune cells is impossible ${ }^{[9]}$. The second therapeutic avenue consists of modulating the key activities and phenotypic attributes of HSC, including averting their proliferative capacity or their tendency to undergo apoptosis ${ }^{[2,8]}$. Tissue fibrogenesis has been considered as obstinately progressive; however, a 
more detailed knowledge of the pathogenetic events underlying fibrogenesis and recent research findings suggest potential reversibility ${ }^{[10]}$. Direct antifibrotic therapies are still lacking with organ transplantation, the sole, major curative option ${ }^{[10]}$. There has been extensive progress in the treatment of chronic liver diseases caused by the hepatitis $\mathrm{C}$ virus $(\mathrm{HCV})$, with approximately 170 million people infected worldwide ${ }^{[11]}$. Two direct acting antivirals (DAAs), telaprevir and boceprevir, along with pegylated interferon, have been the focus of treatments for HCV genotype 1 chronic infection ${ }^{[12]}$. However, a need to develop new DAAs to improve the sustained virological response ${ }^{[12]}$ still exists. Also, because IFN has several side effects, DAA combinations without IFN would be beneficial ${ }^{[11]}$.

A clinical trial by Nelson et al showed that long-term interleukin-10 therapy in chronic hepatitis $C$ patients has an antiinflammatory and proviral effect ${ }^{[13]}$. However, with reduced disease activity, there was an increase in HCV viral loads ${ }^{[13]}$. Although several of the clinical trials for liver fibrosis failed to provide any conclusive outcomes, they helped increase knowledge that may facilitate future clinical trials and ultimately lead to a cure for liver fibrosis ${ }^{[14]}$.

\section{Therapies against liver injury}

The direct relationship between liver inflammation and the progression of fibrosis is well documented. Several antiinflammatory drugs have been tested for their antifibrotic effects during liver inflammation with corticosteroids representing a major group. However, anti-inflammatory corticosteroids showed mixed outcomes in in vitro experiments and clinical trials, and may have undesirable side effects ${ }^{[8,15]}$. The methods targeting cytokines, including TGF- $\beta$ inhibitors that represent the most anti-fibrogenic agent in hepatic fibrogenesis, are being investigated as potential drug candidates in animal models of hepatic injury ${ }^{[1,14]}$. However, further research, including clinical studies, has to be done for therapeutic applications.

\section{Therapies targeting HSC proliferation, apoptosis, and phenotypic alteration}

Studies have shown that stellate cells contribute to the majority of the total fibrogenic population during liver fibrosis and play an important role in orchestrating hepatic immune responses ${ }^{[16]}$. Several therapeutic agents targeting HSC proliferation, intracellular signaling, and cell growth have been studied. Several antioxidant molecules, such as glycyrrhizin, exhibit antifibrotic effects in vitro or in animal studies ${ }^{[17]}$. Growth factors that augment HSC proliferation, including PDGF, are potential targets for drug development, which is discussed in detail in the later part of this review. However, the effects of these compounds in the context of human liver fibrosis are yet to be fully characterized. Vascular endothelial growth factor (VEGF) and its cognate receptors are shown to have roles in hepatic fibrosis development ${ }^{[16]}$. The increase in VEGF concentration may contribute to the progression of fibrosis in smokers who have hepatitis $\mathrm{C}^{[16]}$.

Animal experimentation using vasoconstrictive agents and hepatocyte growth factor revealed that some of these substances may have side effects as potential carcinogenic molecules ${ }^{[8]}$. Studies were reported on the control of liver fibrosis through the modulation of peroxisome proliferatoractivated receptor- $\gamma$ receptor signaling, or through the use of compounds, such as the histone deacetylase inhibitor Trichostatin A, which are effective in manipulating HSC proliferation/activation in in vitro systems and in animal models ${ }^{[18,19]}$. However, future clinical trials have to be carried out on these compounds to prove their efficiencies as antifibrotic drugs.

The preliminary processes in stellate cell activation generally occur simultaneously with progressive changes in the surrounding ECM in the space of Disse ${ }^{[16]}$. The expression of collagens I and III are usually enhanced during liver fibrosis. Synthetic compounds, including HOE077 (ie, pyridine2,4-dicarboxylic-di(2-methoxyethyl)amide), were reported to prevent rat HSC proliferation and collagen synthesis ${ }^{[20]}$. In experimental models, adenoviral expression of TGF- $\beta$ antisense mRNA was shown to prevent liver fibrosis ${ }^{[21]}$, but again the potential benefits of manipulating this pathway in human liver disease conditions have yet to be fully determined.

\section{Novel, marine bioactive compounds as drugs to control liver diseases}

With the current understanding of the molecular aspects of liver inflammation and fibrosis, the development of novel therapeutic interventions to control liver diseases is possible. Current therapies have several major hurdles to overcome for the consideration of marine bioactive compounds as ideal drugs. Accordingly, efforts to develop novel, effective anti-fibrotic drugs presently include the identification of novel compounds that are liver specific with negligible immunogenicity and side effects. Furthermore, these drugs should enhance liver function and the overall health of the affected patients and should be made in abundance at a low $\operatorname{cost}^{[8,14]}$.

\section{Marine bioactive compounds}

Drugs from the marine environment have the potencies to serve as an excellent alternative for established antifibrotic drugs. The oceans comprise more than $70 \%$ of the earth's surface and the diversity of the marine environment contributes to the presence of potent bioactive molecules ${ }^{[17,22]}$. The marine-derived bioactive compounds are structurally and biologically intriguing, and more than 30000 compounds with unique structures and diverse pharmacological activities have been isolated from the marine environment, including plants and invertebrates ${ }^{[23]}$. Some of these compounds that have been extracted and studied show effects (Figure 2) against deadly diseases, including HIV and cancer ${ }^{[24,25]}$. However, only a few marine-based drugs are currently in the market, including Pri-

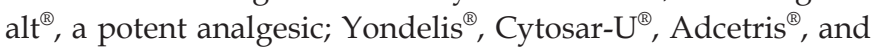
Halaven $^{\circledR}$, antitumour agents; Vira- ${ }^{\circledast}$ and Carragelose ${ }^{\circledR}$, antiviral agents; and Lovaza ${ }^{\circledR}$ for treating hypertriglyceridemia ${ }^{[26]}$. Other potential candidates include Scytonemin, a pigment isolated from cyanobacteria (Figure 3), which inhibits cell cycleregulatory kinases with the potential to cure hyperprolifera- 


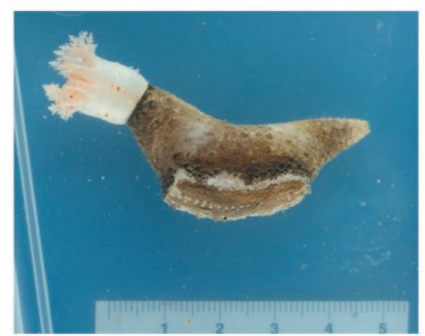

Psolus phantapus

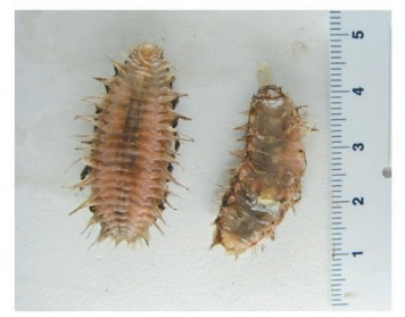

Aphroditella hastata

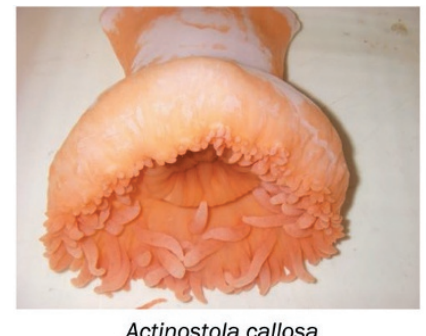

Actinostola callosa

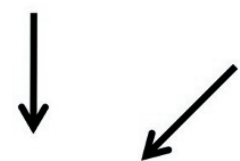

New therapeutic substances

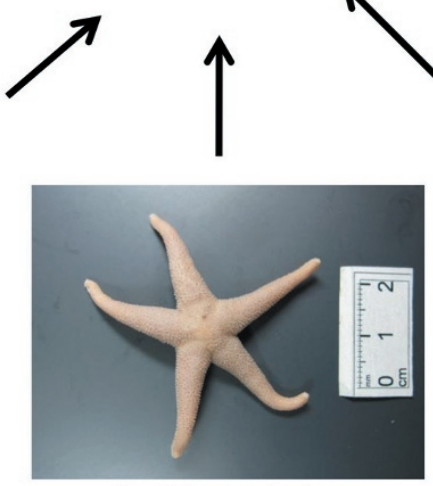

Henricia sanguinolenta

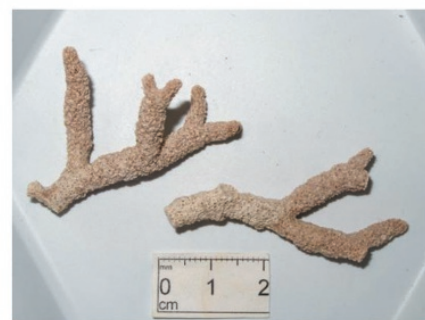

Celleporina surcularis

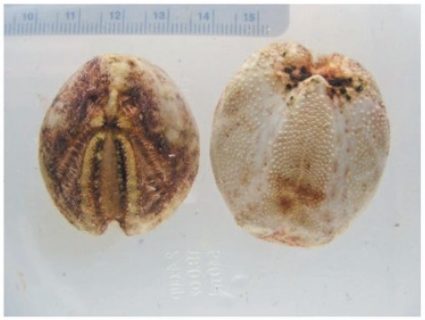

Brisaster fragilis

Figure 2. Potential sources of novel marine bioactive antifibrotic compounds. There are several marine organisms, including Actinostola callosa, Celleporina surcularis, and Psolus phantapus, that might be useful for the isolation of novel therapeutic drugs for the treatment of hepatic fibrosis. The individual figure panels were published with the kind permission of Mr Claude NOZÈRES, Government of Canada, Department of Fisheries and Oceans (www.marinespecies.org/carms/photogallery.php) without any change or modification.

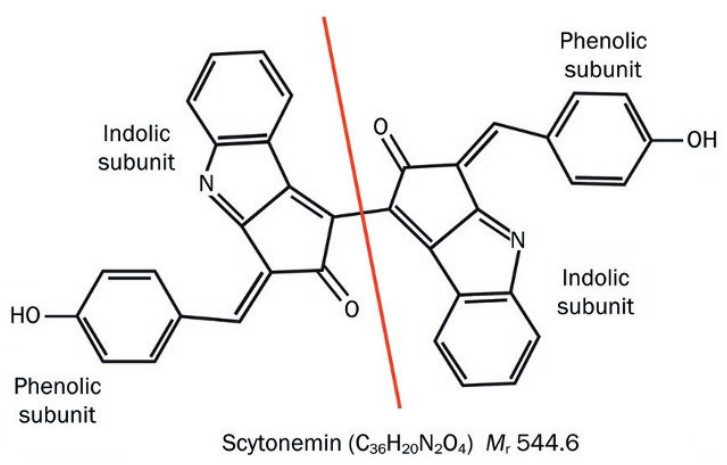

Figure 3. Structure of Scytonemin. The biological pigment Scytonemin is an effective, photo-stable ultraviolet shield in prokaryotes that is composed of two identical subunits (indicated by a red separation line) that each consists of indolic and phenolic subunits ${ }^{[78]}$.

tive disorders, with no chemical toxicity ${ }^{[27]}$. The difficulties in the collection of marine samples and the difficulties in culturing marine microorganisms may underlie the main reasons for the slow progress in this field. Recent advances in technolo- gies to i) isolate and maintain less-culturable marine microbes, ii) to bypass culture-dependent issues through development in the field of metagenomics, and iii) to isolate and characterize secondary metabolites using new robust technologies may promote faster progress ${ }^{[28]}$.

\section{Previous reports on marine-derived compounds with hepatoprotective roles}

Although multiple studies have been carried out to characterize marine bioactive compounds with an aim to cure human disease conditions, the focus on liver diseases is very limited. The hepatoprotective role of brown algae (Padina boergesenii) extract against carbon tetrachloride $\left(\mathrm{CCl}_{4}\right)$-induced oxidative damage and liver fibrosis in Wister rats was reported ${ }^{[29]}$. The authors suggest that the carotenoids present in the extract may contribute to the hepatoprotective effects, as there is a strong correlation between carotenoid content and antioxidant activity ${ }^{[29]}$. The mechanism of action seems to be through cellular membrane stabilization or through antiperoxidase activity, however, the bioactive compounds responsible are unknown and are yet to be isolated and characterized ${ }^{[29]}$. Similarly, ethanolic extract of red algae (Hypnea muciformis) also showed 
hepatoprotective activity against $\mathrm{CCl}_{4}$-induced liver damage in male albino rats; again, the active compounds involved are not isolated or characterized ${ }^{[30]}$. Zhao et al demonstrated the antioxidative and hepatoprotective activities of low molecular fucoidan oligosaccharides (LMFO) isolated from Laminaria japonica in mice with liver injury ${ }^{[31]}$. $\mathrm{CCl}_{4}$ and $D$-galactosamine (D-Gal)/lipopolysaccharides (LPS) were used as two models of liver injury. Pretreatment with LMFO showed protective effects on the hepatocytes and the potential mechanism of action is through their in vivo antioxidant activities ${ }^{[3]}$. Studies by Hong et al have shown the protective effect of fucoidan on acetaminophen-induced liver damage in rats ${ }^{[32]}$. Administration of fucoidan $2 \mathrm{~h}$ prior to acetaminophen reduced liver damage and cell death induced by acetaminophen via antioxidant, anti-inflammatory, and anti-apoptotic effects ${ }^{[32]}$.

Very recently, Esmat and colleagues showed the hepatoprotective effect of bioactive phenolic compounds, including chlorogenic acid, pyrogallol, rutin, and coumaric acid, from the sea cucumber (Holothuria), in thioacetamide (TAA)-induced liver fibrosis in rats ${ }^{[33]}$. High-performance liquid chromatographic analysis (HPLC) of the phenolic compounds revealed the presence of nine components, with chlorogenic $(92.86 \%)$ and ascorbic $(0.067 \%)$ acids as the major and minor component, respectively ${ }^{[33]}$. The subchronic administration of the sea cucumber extract showed no side effects, whereas TAA-administration showed toxic effects, including a reduced percentage of body weight gain, an increased relative weight of body organs, and a low survival rates in animal models ${ }^{[33]}$. The toxic effects of TAA-administration were counterbalanced by the administration of the sea cucumber extract ${ }^{[33]}$. Further, the coadministration of the sea cucumber extract and TAA substantially reduced the hepatotoxic effect of TAA as indicated by the normalization of serum bilirubin, alanine aminotransferase (ALT) and aspartate aminotransferase (AST) activities, and the AST/ ALT ratio, as well as the decrease in serum alkaline phosphatase (ALP) activity, and hepatic triacylglycerol content. Under TAA-induced toxic conditions, the sea cucumber extract also aided in the maintenance of serum total protein, hepatic total protein, DNA and RNA contents, and the protein/DNA ratio, and nullified oxidative stress and decreased liver fibrosis patterns ${ }^{[33]}$. Bioactive compounds/mixtures extracted from holothurians were also shown to have anti-inflammatory, antitumor, and fungicidal activities ${ }^{[34]}$.

Additionally, another recent study by Makhmoor et al showed the hepatoprotective roles of chemical constituents from the marine brown algae Spatoglossum variabile in animal models with $\mathrm{CCl}_{4}$-induced liver disease ${ }^{[35]}$. The antiradical and hepatoprotective effects of the compounds were tested after analyzing the radical scavenging potential and $\beta$-glucuronidase inhibition using in vitro tests. The tested compounds exhibited antiradical activity against 1,1-diphenyl2-picrylhydrazyl radicals along with superoxide anion scavenging effects ${ }^{[35]}$. In animal models, the orally pre-administered compounds 2-4 significantly blocked the $\mathrm{CCl}_{4}$-induced elevation of serum biochemical markers ${ }^{[35]}$. These studies provide basic scientists and clinicians with evidence that novel, bioactive, and antioxidant molecules or compounds isolated from these organisms may assist in the development of novel drugs/means to treat liver diseases.

\section{Marine-derived compounds worthy of investigation for potential therapeutic benefit in liver diseases}

A repertoire of marine bioactive molecules has been shown to have profound effects in manipulating human pathophysiological conditions. Because liver disease also generally involves inflammation and fibrosis, compounds affecting common inflammatory pathways may also have significance in hepatic fibrogenesis. Some of the marine compounds affecting these pathways that will be later discussed have the potential to be tested in liver disease or can act as a lead for therapeutic agents.

\section{Compounds with anti-inflammatory properties coX pathway inhibitors}

COX-1 and COX-2 enzymes are the targets of several nonsteroidal anti-inflammatory drugs which are commonly used but generally have some severe side effects, such as gastric ulcerations. Natural compounds, in contrast, generally have the advantage of less adverse side effects, such as the terpenoid Pacifenol (Figure 4) that was isolated from seaweeds of the marine alga Laurencia claviformis and later found naturally in Laurencia tasmanica ${ }^{[34]}$. Likewise, Epitaondiol (Figure 4), another terpenoid from seaweeds of Stypopodium flabelliforme, has an antioxidant effect, inhibiting eicosanoid production

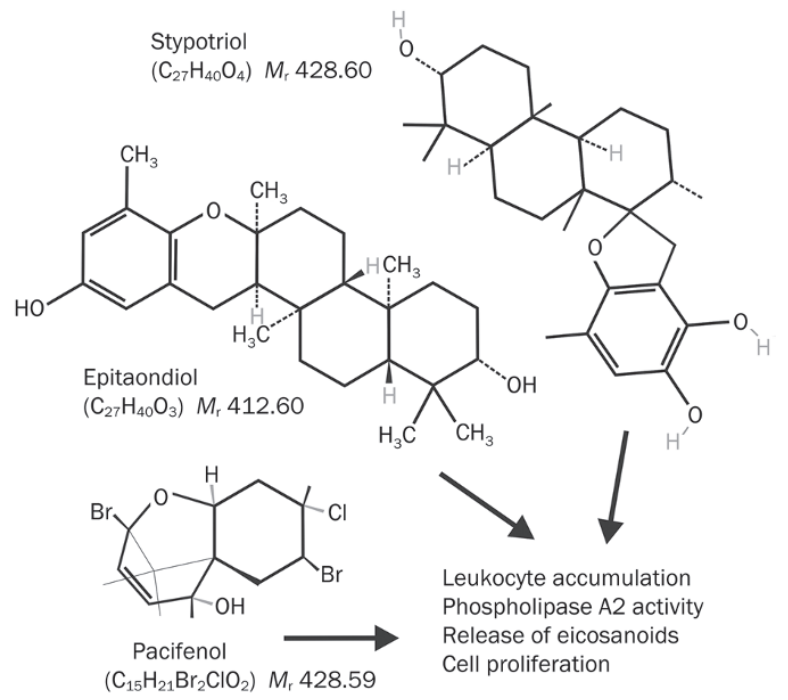

Figure 4. Structure and anti-inflammatory activity of Pacifenol, Epitaondiol, and Stypotriol. Epitaondiol is a polycyclic meroditerpenoid containing two fused six-membered rings forced into the twist-boat conformation ${ }^{[79]}$. Likewise, Stypotriol (also known as Stypotriol triacetate) is a pentacyclic ichthyotoxin with a meroditerpenoid structure. Pacifenol is a polyhalogenated sesquiterpene consisting of three isoprene units with a total of $15 \mathrm{C}$ atoms ${ }^{[80]}$. All three of these drugs interfere to a different degree with leukocyte accumulation, phospholipase A2 activity, release of eicosanoids and cell proliferation. The precise mode of action for each drug is described elsewhere ${ }^{[81,82]}$. 
through the inhibition of phospholipase A2 and COX $-2^{[36]}$. Stypotriol triacetate (Figure 4 ) is a meroditerpenoid from the same seaweed that inhibits phospholipase A2 and the expression of elastase, and also has antibacterial and anti-proliferative activities ${ }^{[36]}$.

\section{Marine steroids}

Several uncommon steroids with anti-inflammatory properties are abundantly found in marine organisms (Figure 5), including i) the polyoxygenated steroid contignasterol isolated from the marine sponge Petrosia contignata that inhibits platelet aggregation, ii) the pentacyclic polyhydroxylated steroid xestobergsterol isolated from the marine sponge Xestospongia bergquisicta, and iii) clathriols $\mathrm{A}$ and $\mathrm{B}$ that are isolated from the marine sponge Clathria lissosclera ${ }^{[36]}$.

\section{Nuclear factor kappa beta (NF-KB) and TGF- $\beta$ pathway inhibitors}

The NF-kB pathway is strongly activated following the transformation of quiescent to activated HSCs during liver injury ${ }^{[37]}$. $\mathrm{NF}-\mathrm{\kappa B}$ responsive genes that are induced in activated HSC include diverse cytokines, chemokines, and adhesion molecules $^{[37]}$. The effect of Hymenialdisine (Figure 5), a marinederived natural product, on inhibiting the NF- $\mathrm{kB}$ pathway and preventing IL- 8 expression after stimulation with tumor necrosis factor- $a$, lipopolysaccharide, or phorbol myristate acetate was comprehensively reported in the human histio- cytic leukemia cell line U937 $7^{[37]}$. Speculation that this molecule or its derivatives will evolve the same therapeutic activity during HSC activation and transdifferentiation is worth consideration.

TGF- $\beta$ is a key regulator in chronic liver disease, influencing the plasticity of HSC and contributing to all of the stages of disease progression ${ }^{[1]}$. The biological effects of TGF- $\beta$ are exerted through a distinct network of different receptors that are structurally similar serine/threonine kinases and several intracellular signaling mediators commonly known as Smad proteins $^{[1]}$. The TGF- $\beta$ pathway is further controlled by antagonistic acting regulators and negative feedback inhibitor loops, which offers a large variety of attractive drug targets ${ }^{[38]}$. Hyrtiosal, an inhibitor of protein tyrosine phosphatase $1 \mathrm{~B}$, isolated from the marine sponge Hyrtios erectus, affects TGF- $\beta / S m a d 2$ activation and signaling ${ }^{[39]}$. The identification of novel marinederived molecules that exhibit similar effects on the TGF- $\beta$ pathway or its target gene expression would be very useful.

\section{Compounds with antioxidant properties}

The important role of oxidative stress in the development of liver injury and activation of HSC is well documented ${ }^{[40]}$. Antioxidative active substances, such as the traditional herbal Chinese medicine Sho-saiko-to, are effective natural drugs in preventing hepatic fibrosis ${ }^{[41]}$. The antifibrotic effect of Shosaiko-to and its ingredients, confirmed in many independent

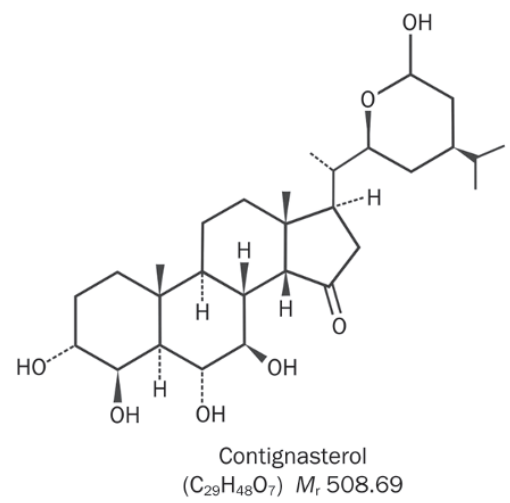
$\left(\mathrm{C}_{29} \mathrm{H}_{48} \mathrm{O}_{7}\right) \quad M_{\mathrm{r}} 508.69$

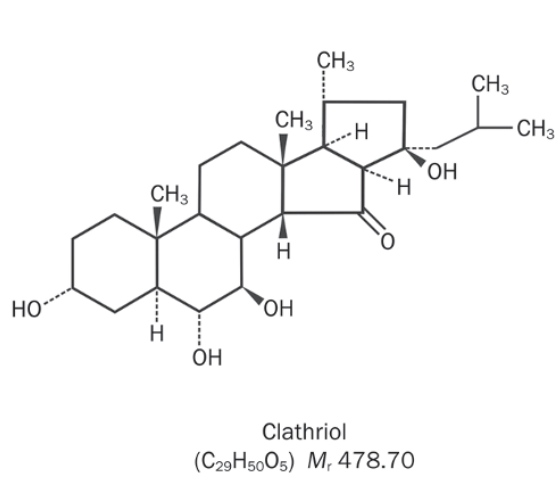

$\left(\mathrm{C}_{29} \mathrm{H}_{50} \mathrm{O}_{5}\right) \quad M_{\mathrm{r}} 478.70$

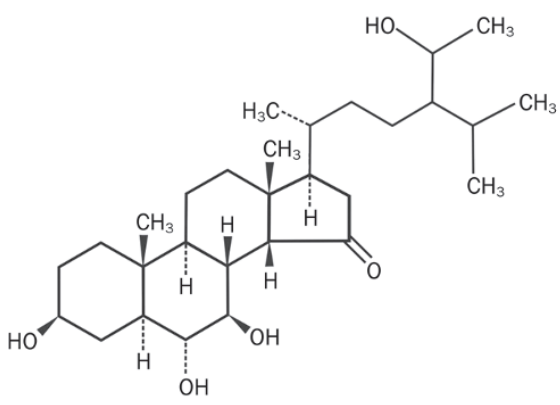

Xestobergsterol A $\left(\mathrm{C}_{27} \mathrm{H}_{44} \mathrm{O}_{5}\right) M_{\mathrm{r}} 448.64$<smiles>CC1(C=O)CC2(C)[C@](C)(CC[C@H]3C(C)(C)CCC[C@]32C)C1C[C@H](O)c1ccoc1</smiles>

Hyrtiosal $\left(\mathrm{C}_{25} \mathrm{H}_{38} \mathrm{O}_{3}\right) \quad \mathrm{M}_{\mathrm{r}} 386.57$

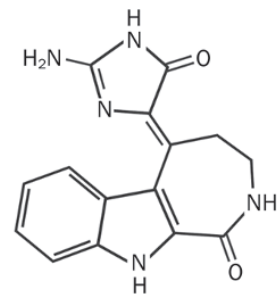

Hymenialdisine analogue 1 $\left(\mathrm{C}_{15} \mathrm{H}_{13} \mathrm{~N}_{5} \mathrm{O}_{2}\right) \quad M_{\mathrm{r}} 295.3$

Figure 5. Structure of contignasterol, xestobergsterol A, and clathriols A/B. Contignasterol is a highly oxygenated steroid with a rare 14 beta configuration $^{[83]}$ that dose-dependently inhibits histamine release ${ }^{[84]}$. Likewise, the pentacyclic polyhydroxylated sterol Xestobergsterol $\mathrm{A}$ interferes with histamine release and further inhibits inositol triphosphate (IP3) generation, membrane-bound phosphatidylinositol-specific phospholipase C (PI$\mathrm{PLC}$ ) activity, and $\mathrm{Ca}^{2+}$-mobilization from intracellular $\mathrm{Ca}^{2+}$ stores ${ }^{[85]}$. The polyoxygenated steroid Clathriol has the capacity to inhibit the production of superoxide from human peripheral blood neutrophils, which is a key factor implicated in the pathogenesis of inflammatory disorders ${ }^{[86]}$. 
studies and animal models, enabled its availability in North America without a prescription as a natural, alternative approach for patients who are non-responsive to standard medical treatment or are not candidates for interferon based treatments. In addition, the anti-inflammatory, anti-fibrogenic, and immune modulating activities of this natural component have enforced studies aiming to identify novel antioxidant natural substances. Although there were reports of hepatic injury caused by this compound, the case reports were few and it was difficult to determine whether the hepatic injury was entirely due to the Sho-saiko-to or due to the coadministration of interferon ${ }^{[42]}$. Silymarin, isolated from a medicinal plant Silybum marianum, is another well characterized natural compound with hepatoprotective effects mainly due to its antioxidant effect ${ }^{[43]}$. Edible seaweeds are generally a rich source of antioxidants. The compounds derived from these marine plants show anti-inflammatory, anticoagulant, and antitumoral activities and are known to reduce oxidative stress via their free radical scavenging properties. Kelman et al analyzed the antioxidant activities of 30 species of Hawaiian algae and found that the major active compound is the carotenoid, fucoxanthin ${ }^{[44]}$. This unique carotenoid, primarily isolated from brown algae and diatoms, shows a higher antioxidant activity than other antioxidants, including tocopherols, potentially due to the presence of the allenic moiety ${ }^{[4]}$. Fucoxanthin also shows an in vivo antioxidant effect on obese/diabetic mouse models and is worth being tested in an experimental model for liver disease $\mathrm{e}^{[34]}$. Another major antioxidant found in algae is Astaxanthin from Haematococcus pluvialis ${ }^{[34]}$. Balaji and coworkers demonstrated the antihepatotoxic nature of Ulva reticulata extract on acetaminophen-induced liver damage in rats ${ }^{[45]}$. A number of studies have demonstrated that peptides derived from different marine protein hydrolysates act as potential antioxidants. They have been isolated from marine organisms, such as the jumbo squid, sea cucumber, and tuna, and show greater antioxidant properties than a-tocopherol (vitamin E) in certain cases ${ }^{[46]}$. Similarly, polysaccharide from Apostichopus japonicus shows in vitro free radical (hydroxyl and superoxide) scavenging activity ${ }^{[47]}$, again demonstrating that novel therapeutic, antioxidant agents can be identified from the marine world with a potential to be used as pharmaceuticals, nutraceuticals, or as substitution for synthetic antioxidants $^{[47]}$.

\section{Compounds affecting PDGF receptor- $\beta$ signaling}

The PDGF signaling network that triggers a complexity of different cellular pathways consists of a family of four homodimers (PDGF-AA, PDGF-BB, PDGF-CC, and PDGF$\mathrm{DD})$; one heterodimer (PDGF-AB); and three types of dimeric glycoprotein receptors (PDGFR- $\alpha$, PDGFR- $\alpha \beta$, and PDGFR- $\beta$ ) (Figure 6). The elevated expression of the PDGF isoforms and its receptors has been found in fibrotic liver tissue ${ }^{[48]}$. In particular, similar to intestinal smooth muscle cells during inflammation, the fundamental role of PDGF-BB and one of its receptors, ie, PDGFR- $\beta$, in the formation of hepatic fibrosis was reported ${ }^{[48,49]}$.

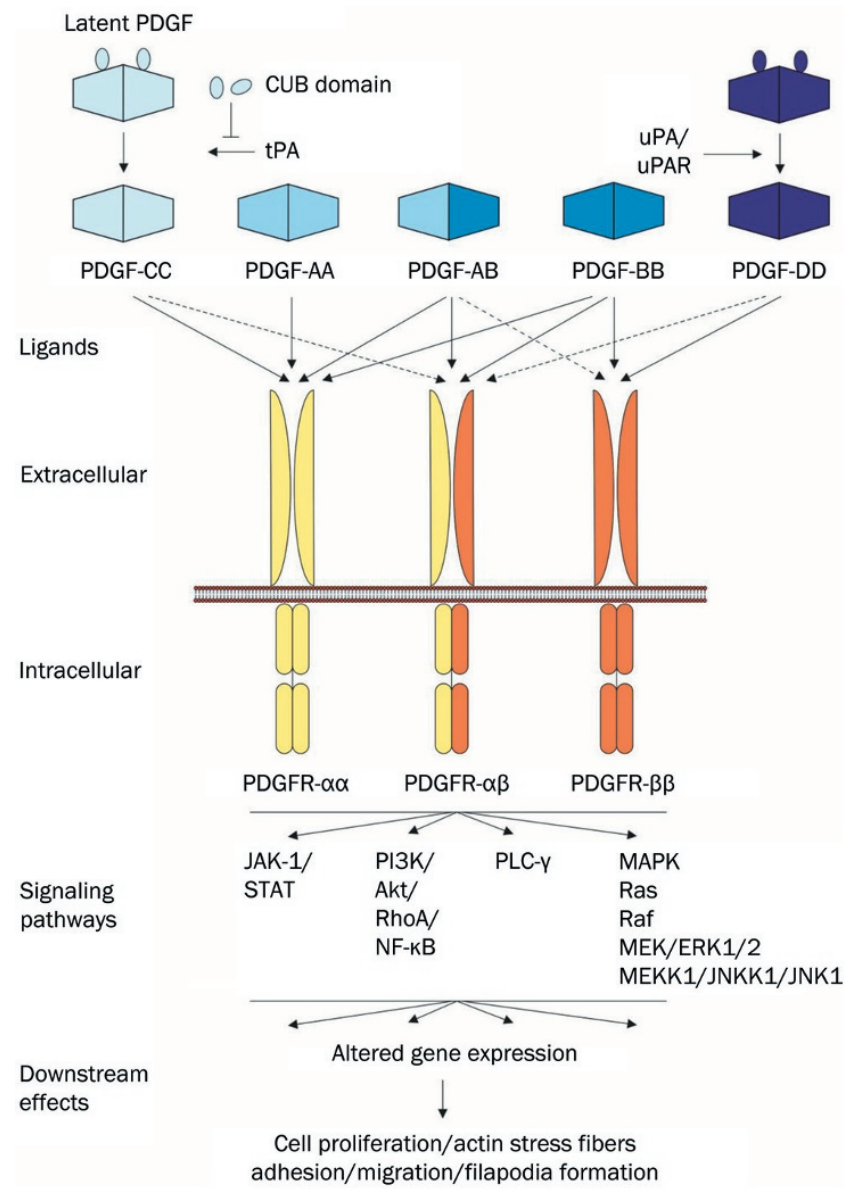

Figure 6. PDGF signaling in hepatic fibrosis. While PDGF-A and -B are secreted as bioactive homo- or heterodimers, PDGF-C and -D are secreted as latent homodimers that become activated by proteolytic separation of the inhibitory CUB domains, a process that is mediated by the activity of the tissue plasminogen activator (tPA) or urokinase plasminogen activator and its receptor system (UPA/UPAR). The PDGF ligands bind to specific tyrosine kinase receptors that, upon ligand binding, lead to the formation of three different dimeric receptor combinations, namely PDGFR- $\alpha \alpha$, PDGFR- $\alpha \beta$, and PDGFR- $\beta \beta$. During activation, the receptors become phosphorylated at specific tyrosine residues and subsequently trigger the activation of a wide variety of intracellular signaling cascades that leads to altered gene expression. As a consequence, the increase of PDGF during liver insult results in increased cell proliferation and actin stress fiber formation. In addition, the different PDGF isoforms modulate cellular adhesion, migration, and filapodia formation.

\section{Substances isolated from sponges}

Recently, several reports were published describing the effects of marine bioactive compounds on PDGF-BB signaling. A recent study by Choi et al demonstrated that Sponge-derived acetylenic alcohols and petrosiols inhibit PDGF-induced proliferation and the migration of vascular smooth muscle cells ${ }^{[50]}$. These drugs likely have the capacity to inhibit the phosphorylation of PDGFR- $\beta$ and its downstream effectors phospholipase- $\gamma 1, \mathrm{AKT} / \mathrm{PKB}$, and extracellular signal-regulated kinases ERK1/2. In similar studies, Pinchuk and col- 
leagues showed the inhibitory effects of the pyrazin-2(1H)-one scaffold from hamacanthins, which were also isolated from a marine sponge and are highly potent in binding and inhibiting PDGFR- $\beta^{[51]}$. Based on the outstanding role of the PDGF system in liver fibrosis, it will be extremely worthwhile to study the effects of these molecules on the setting of experimental liver disease models.

\section{Substances isolated from the sea cucumber}

Philinopside A is a sulfated saponin isolated from the sea cucumber Pentacta quadrangularis. It shows a potent inhibitory activity against receptor-tyrosine kinases (RTKs), including PDGFR- $\beta$, and dose-dependently inhibited the proliferation, migration, and tube formation of human microvascular endothelial cells ${ }^{[52]}$. Further studies will help to better understand the mechanism of its action and the potential modifications on the saponin backbone may enhance the specificity for individual RTKs.

\section{Additional applications of marine-derived compounds to control liver fibrosis or to enhance recovery}

Marine polysaccharides: for hepatic cell therapy and tissue engineering

Marine polysaccharides already have several important medical, pharmaceutical, and biotechnological applications, which include the fabrication of wound dressings, high polymer biomaterials, and tissue scaffolds ${ }^{[53]}$. However, these compounds, potentially safer than mammalian polysaccharides, are still under-exploited for their potential applications in hepatology or drug discovery and should be given further consideration $^{[53]}$.

During liver failure, the complication of liver transplant necessitates the use of tissue engineering in which autonomous cells have to be seeded for regeneration on a scaffold with an abundance of oxygen, nutrients, and growth factors, such as PDGF. A decade ago, the Cohen group demonstrated the use of porous alginate scaffolds that were prepared from brown sea weed for the efficient seeding and survival of hepatocytes $^{[54]}$.

Apart from its application as a biomedical material, marinederived chitosan demonstrates protective effects against liver damage. Yan et al demonstrated the protective effect of chitosan oligosaccharide and its derivatives against $\mathrm{CCl}_{4}$-induced liver damage by pretreatment ${ }^{[55]}$. $\beta$-Chitosan isolated from the squid Sepioteuthis lessoniana showed hepatoprotective activity against $\mathrm{CCl}_{4}$-induced oxidative stress in Wistar rats ${ }^{[56]}$. Along with the stabilization of various liver marker enzyme activities, histopathological observations also suggested that the hepatoprotective activity of $\beta$-chitosan is possibly due to its antioxidant and antilipidemic properties ${ }^{[56]}$. Recently, another study by Ramasamy et al showed the antioxidative and hepatoprotective roles of chitosan from Sepia kobiensis against $\mathrm{CCl}_{4}$ induced liver damage in rats ${ }^{[57]}$. The changes in the circulatory and hepatic antioxidant defense systems were normalized by the administration of chitosan ${ }^{[57]}$.

\section{Chitosan-based microgels for 'smart' drug-delivery}

Microgels based on chitosan from shrimp and crab shells can be used in vivo for the 'smart' delivery of drugs or growth factors. Recently, Gu et al reported a closed-loop insulin delivery platform using injectable self-regulated microgels that facilitate insulin release when subjected to hyperglycemic conditions ${ }^{[58]}$. Most interestingly, these microgels sufficiently promoted a reduction of blood glucose levels in a mouse model of type 1 diabetes $^{[58]}$. It is tempting to speculate that similar technology and scaffolds can be developed that allow the administration of anti-inflammation drugs, therapeutic proteins, growth factors, or marine-derived compounds.

\section{Fish oil as a supplement or as a drug}

The beneficiary effects of fish oil or its constituents on hepatic protection have gained recent attention. Depner and colleagues showed that menhaden oil decreased several, but not all, high-fat diet-induced markers of hepatic damage, steatosis, inflammation, and fibrosis in mice ${ }^{[59]}$. N-3 polyunsaturated fatty acid (PUFA), a constituent of fish oil, was shown to regulate hepatic gene transcription ${ }^{[60]}$. The administration of dietary fish oil resulted in reduced damage in the liver tissue of Mus musculus, suggesting that long chain PUFA, such as eicosapentaenoic acid and docosahexaenoic acid, may serve as a preventive agent for hepatic cirrhosis ${ }^{[61]}$. Similarly, the supplementation of fish oil rich in PUFA showed an in vivo protective effect against oxidative stress-induced DNA damage caused by the administration of ferric nitrilotriacetate in rat liver ${ }^{[62]}$. Studies also showed the hepatoprotective effects of fish oil against liver damage induced by several agents, including lipopolysaccharides ${ }^{[63]}$, cisplatin ${ }^{[64]}$, and acetaminophen $^{[65]}$, in various in vivo models. The novel constituents of fish oil as supplements or drugs might therefore be beneficial in controlling critical pathways in liver pathophysiology.

\section{Marine biodiversity in 0 man and the potential for identifying novel hepatoprotective therapeutic agents}

We have initiated efforts to search for novel bioactive compounds from the unexplored marine environment in Oman. Compared to the neighboring countries in the Arabian Peninsula, Oman has the longest coastal habitats along the Arabian Sea, the Gulf of Oman, and the Arabian Gulf. Oman contributes a rich environment to marine biodiversity, one example is Ras Al-Hadd, one of the largest nesting beaches for marine turtles around the world ${ }^{[66]}$. A complete taxa of Oman's marine flora and fauna is needed for an extensive investigation, but so far, little has been done. No studies related to the majority of marine organisms have been completed. Fisheries are one of the most vital resources to the Oman economy, after crude oil. Noteworthy, approximately 134000 metric tons of fish are produced annually in Oman with an average income of 160 million USD ${ }^{[67]}$. Due to the extensive fishing, it was reported that 20 fish species are already on the verge of extinction $^{[67]}$, while the fate of many other species has not yet been documented. Large scale coral reef damage is irreversible to 
some habitats, which has already taken place in Oman. Thus, tremendous efforts must be taken immediately to preserve the marine environment and to explore, identify, and characterize novel bioactive molecules from this rich environment.

Some fungi secrete mycotoxins, such as aflatoxins and fumonisins, that when ingested through contaminated food may cause liver toxicity, which can ultimately lead to cancer. Studies in Oman reported aflatoxin contaminations in spices and black tea ${ }^{[68,69]}$. Recent studies in Oman used Hibiscus sabdariffa extract and Nigella sativa oil to prevent the production of aflatoxin B1 and used baobab (Adansonia digitata) extracts as a biocontrol to prevent the growth and aflatoxin production by Aspergillus flavus and A parasiticus ${ }^{[70,71]}$. Similar studies can be carried out using local marine flora and fauna to cure liver diseases. Populations that live in villages near industrial areas have higher rates of liver diseases due to the continuous exposure to heavy metals. Patients with liver diseases were found to have higher levels of $\mathrm{Cr}^{[72]}$. Studies in Oman have shown that treated sewage effluent contains different types of heavy metals that contaminate terrestrial and marine environments and underground water, leading to the accumulation of metals in tomato crops, marine fish and turtles ${ }^{[73-76]}$, which may have long-term impacts on human health. Half of the chronic liver diseases in Oman are reported to be of hereditary origin $^{[77]}$. Hence, in addition to the ongoing efforts to prevent the incidence of liver diseases in Oman and also worldwide, it is imperative and important to focus on the local, rich marine resources for the identification of novel hepatoprotective agents (Figure 7), most of which have been poorly characterized with respect to liver diseases.

\section{Conclusions}

Liver fibrosis and cirrhosis, induced by a plenitude of different mechanisms, are a major healthcare burden worldwide. The sole removal of the causal agent is not an efficient approach to cure advanced stages of fibrosis. Although there is progress in liver transplantation and viral hepatitis treatment, these techniques have some limitations. Issues regarding organ availability for transplantation, organ compatibility, and the health of the donor and patient complicate the process. Hence, there is a great need for novel therapies for liver fibrosis, which represents a reversible pathological condition. Antifibrotic drugs targeting hepatic stellate cell activation or phenotypic alteration have a high potential to develop as novel therapeutic agents. The marine-derived environment represents an unexplored area for identifying novel hepatoprotective drugs. Although several compounds have been isolated and tested in other human disease conditions (Table 1), there are presently very few studies focused on their efficacies in hepatic lesions. Due to the prevalence of liver diseases and the presence of environmental/other factors contributing to their development, more detailed studies related to liver diseases are urgently needed in Oman and other countries. The effect of water and food contamination and their impact on liver functionality requires further extensive investigation. Because Oman is rich with marine flora and fauna, these organisms could provide an important source of novel biomedical products for the treatment of liver disease, as well as many other diseases. Therefore, successful collaborations of basic scientists across different academic disciplines, clinicians, and industrial partners are compulsory and urgently needed to

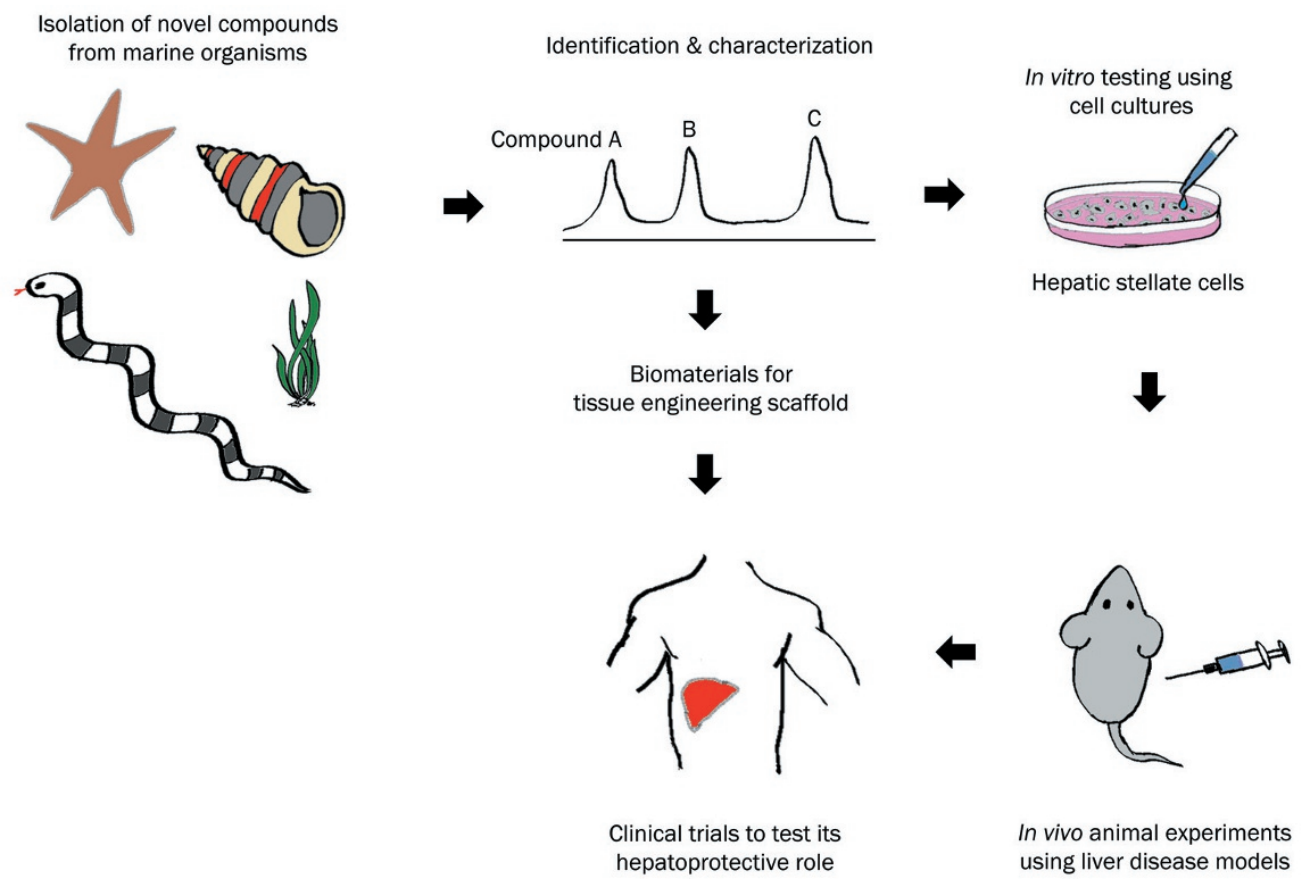

Figure 7. Graphical abstract showing a summary of the review article. Novel bioactive compounds are isolated from the marine environment and are characterized before in vitro testing. The compounds showing in vitro activities will be screened for in vivo activities using animal models and ultimately for their hepatoprotective roles in humans. 
Table 1. A list of marine bioactive compounds or extracts with reported or potential hepatoprotective roles.

\begin{tabular}{|c|c|c|c|c|}
\hline Activities & & Organism & Compound/extract & Reference \\
\hline \multirow[t]{12}{*}{ Antioxidant } & Algae & Ulva reticulata & Extract & Balaji et al, $2004^{[45]}$ \\
\hline & & Haematococcus pluvialis & Astaxanthin & D'Orazio et al, $2012^{[34]}$ \\
\hline & & Cymopolia barbata & Cymopol & Takamatsu et al, $2003^{[87]}$ \\
\hline & & Avrainvillea longicaulis & Avrainvilleol & Takamatsu et al, $2003^{[87]}$ \\
\hline & & Halimeda opuntia & Polyphenols & Silva et al, 2012[88] \\
\hline & & Undaria pinnatifida & Fucoxanthin & D'Orazio et al, $2012^{[34]}$ \\
\hline & Hard clam & Gelonia erosa & Ethylacetate & Yeh et al, 2012 $2^{[89]}$ \\
\hline & & Paphia undulata & Hydrolysates & He et al, 2013 ${ }^{[90]}$ \\
\hline & Sea cucumber & Apostichopus japonicus & Polysaccharide & Liu et al, 2012 $2^{[47]}$ \\
\hline & & Holothuria atra & Extract & Esmat et al, 2013 ${ }^{[30]}$ \\
\hline & & $\begin{array}{l}\text { Holothuria edulis and Stichopus } \\
\text { horrens }\end{array}$ & Extract & Althunibat et al, $2013^{[91]}$ \\
\hline & & Stichopus japonicus & Peptides & Zhou et al, 2012 ${ }^{[92]}$ \\
\hline \multirow[t]{9}{*}{ Antiinflammatory } & Algae & Laureafncia claviformis & Pacifenol & Balaji et al, $2004^{[45]}$ \\
\hline & & Stypopodium flabelliforme & Epitaondiol, Stypotriol triacetate & Pereira et al, 2011 ${ }^{[82]}$ \\
\hline & & Undaria pinnatifida & Fucoidan & Hong et al, 2012 $2^{[93]}$ \\
\hline & Gorgonian & Junceella fragilis & Frajunolides & Liaw et al, 2010 \\
\hline & Molluscs & $\begin{array}{l}\text { Mytilus galloprovincialis }(L) \text { and } \\
\text { Rapana venosa }\end{array}$ & Amino acids & Baidu et al, 2010 ${ }^{[95]}$ \\
\hline & Sea cucumber & Holothuria atra & Extract & Esmat et al, 2013 ${ }^{[33]}$ \\
\hline & & Holothuria nobilis & Extract & Whitehouse \& Fairlie ${ }^{[96]}$ \\
\hline & Sponge & Plakortis angulospiculatus & Plakortide P & Kossuga et al, 2008 ${ }^{[97]}$ \\
\hline & & Stylissa carteri & Carteramine A & Kobayashi et al, $2007^{[98]}$ \\
\hline \multirow[t]{3}{*}{ Interfering PDGF-R $\beta$ signaling } & Sponge & Petrosia strongylata & Acetylenic alcohols, petrosiols & Choi et al, 2013 ${ }^{[50]}$ \\
\hline & & Rhaphisia lacazei & Pyrazin-2(1H)-one & Pinchuk et al, $2013^{[51]}$ \\
\hline & Sea cucumber & Pentacta quadrangulari & Philinopside A & Tong et al, $2005^{[52]}$ \\
\hline \multirow[t]{6}{*}{ Interfering NF-kB pathway } & Algae & $\begin{array}{l}\text { Nostoc commune and Spirulina } \\
\text { platents }\end{array}$ & Extract & Ku et al, $2013^{[99]}$ \\
\hline & & Cladophora fascicularis & Porphyrinolactone & Huang et al, $2007^{[100]}$ \\
\hline & Sponge & Fasciospongia cavernosa & Cacospongionolide B & Posadas et al, 2013 ${ }^{[101]}$ \\
\hline & & Petrosaspongia nigra & Petrosaspongiolide M & Posadas et al, $2013^{[101]}$ \\
\hline & Cyanobacteria & Nostoc commune & Scytonemin & Nagle et al, 2004 $4^{[102]}$ \\
\hline & & Lyngbya majuscula & Curacin A & Catassi et al, 2006 ${ }^{[103]}$ \\
\hline \multirow[t]{2}{*}{ Interfering TGF- $\beta$ pathway } & Sponge & Hyrtios erectus & Hyrtiosal & Sun et al, 2007 \\
\hline & Microalgae & Navicula incerta & Peptides (NIPP-1 \& NIPP-2) & Kang et al, $2013^{[104]}$ \\
\hline \multirow[t]{2}{*}{$\begin{array}{l}\text { Interfering cyclooxygenase } \\
\text { pathway }\end{array}$} & Soft coral & Lobophytum crassum & $\begin{array}{l}\text { Cembranoids \& Crassumolides } \\
\text { A \& C }\end{array}$ & Chao et al, 2008 ${ }^{[105]}$ \\
\hline & & Lobophytum duru & Durumolides A-C & Cheng et al, 2008 ${ }^{[106]}$ \\
\hline
\end{tabular}


isolate and evaluate these novel drugs.

\section{Abbreviations}

HSC, hepatic stellate cells; TGF- $\beta$, transforming growth factor $\beta$; PDGF- $\beta$ platelet-derived growth factor $\beta$; PPAR- $\gamma$ receptor, peroxisome proliferator-activated receptor- $\gamma$; COX-1/COX2, cyclooxygenase 1 or 2; NF-kB, Nuclear Factor Kappa Beta; $\mathrm{HBeAg}$, Hepatitis B e-Antigen; $\mathrm{CCl}_{4}$, Carbon tetrachloride.

\section{Acknowledgements}

The authors thank Mr Claude NOZÈRES, Canadian Register of Marine Species (CaRMS), Government of Canada, Department of Fisheries and Oceans (www.marinespecies.org/carms/photogallery.php) for kindly providing pictures of marine organisms.

\section{References}

1 Gressner AM, Weiskirchen R. Modern pathogenetic concepts of liver fibrosis suggest stellate cells and TGF-beta as major players and therapeutic targets. J Cell Mol Med 2006; 10: 76-99.

2 Friedman SL. Hepatic stellate cells: protean, multifunctional, and enigmatic cells of the liver. Physiol Rev 2008; 88: 125-72.

3 Winau F, Hegasy G, Weiskirchen R, Weber S, Cassan C, Sieling PA, et al. Ito cells are liver-resident antigen-presenting cells for activating $T$ cell responses. Immunity 2007; 26: 117-29.

4 Kordes C, Sawitza I, Muller-Marbach A, Ale-Agha N, Keitel V, Klonowski-Stumpe $\mathrm{H}$, et al. $\mathrm{CD}_{133^{+}}$hepatic stellate cells are progenitor cells. Biochem Biophys Res Commun 2007; 352: 410-7.

5 Zeisberg M, Yang C, Martino M, Duncan MB, Rieder F, Tanjore H, et al. Fibroblasts derive from hepatocytes in liver fibrosis via epithelial to mesenchymal transition. J Biol Chem 2007; 282: 23337-47.

6 Borkham-Kamphorst E, Herrmann J, Stoll D, Treptau J, Gressner AM, Weiskirchen R. Dominant-negative soluble PDGF-beta receptor inhibits hepatic stellate cell activation and attenuates liver fibrosis. Lab Invest 2004; 84: 766-77.

7 Tacke F, Weiskirchen R. Update on hepatic stellate cells: pathogenic role in liver fibrosis and novel isolation techniques. Expert Rev Gastroenterol Hepatol 2012; 6: 67-80.

8 Murphy F, Arthur M, Iredale J. Developing strategies for liver fibrosis treatment. Expert Opin Investig Drugs 2002; 11: 1575-85.

9 Ishibashi H, Komori A, Shimoda S, Gershwin ME. Guidelines for therapy of autoimmune liver disease. Semin Liver Dis 2007; 27: 214-26.

10 Ramachandran P, Iredale JP. Liver fibrosis: a bidirectional model of fibrogenesis and resolution. QJM 2012; 105: 813-7.

11 Asselah T, Marcellin P. Interferon free therapy with direct acting antivirals for HCV. Liver Int 2013; 33 Suppl 1: 93-104.

12 Zeuzem S, Andreone P, Pol S, Lawitz E, Diago M, Roberts S, et al. REALIZE Study Team. Telaprevir for retreatment of HCV infection. N Engl J Med 2011; 364: 2417-28.

13 Nelson DR, Tu Z, Soldevila-Pico C, Abdelmalek M, Zhu H, Xu YL, et al. Long-term interleukin 10 therapy in chronic hepatitis $C$ patients has a proviral and anti-inflammatory effect. Hepatology 2003; 38: 859-68.

14 Friedman SL, Sheppard D, Duffield JS, Violette S. Therapy for fibrotic diseases: nearing the starting line. Sci Transl Med 2013; 5: 167sr1.

15 Niki T, Schuppan D, de Bleser PJ, Vrijsen R, Pipeleers-Marichal M, Beyaert R, et al. Dexamethasone alters messenger RNA levels but not synthesis of collagens, fibronectin, or laminin by cultured rat fatstoring cells. Hepatology 1996; 23: 1673-81.

16 Friedman SL. Mechanisms of hepatic fibrogenesis. Gastroenterology
2008; 134: 1655-69.

17 Park EJ, Ko G, Kim J, Sohn DH. Antifibrotic effects of a polysaccharide extracted from Ganoderma lucidum, glycyrrhizin, and pentoxifylline in rats with cirrhosis induced by biliary obstruction. Biol Pharm Bull 1997; 20: 417-20.

18 Miyahara T, Schrum L, Rippe R, Xiong S, Yee HF Jr, Motomura K, et al. Peroxisome proliferator-activated receptors and hepatic stellate cell activation. J Biol Chem 2000; 275: 35715-22.

19 Niki T, Rombouts K, De Bleser P, De Smet K, Rogiers V, Schuppan $D$, et al. A histone deacetylase inhibitor, trichostatin A, suppresses myofibroblastic differentiation of rat hepatic stellate cells in primary culture. Hepatology 1999; 29: 858-67.

20 Aoyagi M, Sakaida I, Suzuki C, Segawa M, Fukumoto Y, Okita K. Prolyl 4-hydroxylase inhibitor is more effective for the inhibition of proliferation than for inhibition of collagen synthesis of rat hepatic stellate cells. Hepatol Res 2002; 23: 1-6.

21 Arias M, Sauer-Lehnen S, Treptau J, Janoschek N, Theuerkauf I, Buettner $\mathrm{R}$, et al. Adenoviral expression of a transforming growth factor-beta1 antisense mRNA is effective in preventing liver fibrosis in bile-duct ligated rats. BMC Gastroenterol 2003; 3: 29.

22 Donia M, Hamann MT. Marine natural products and their potential applications as anti-infective agents. Lancet Infect Dis 2003; 3: 338-48.

23 Faulkner DJ. Marine pharmacology. Antonie Van Leeuwenhoek 2000; 77: 135-45.

24 Gochfeld DJ, El Sayed KA, Yousaf M, Hu JF, Bartyzel P, Dunbar DC, et al. Marine natural products as lead anti-HIV agents. Mini Rev Med Chem 2003; 3: 401-24.

25 Cragg GM, Newman DJ. Antineoplastic agents from natural sources: achievements and future directions. Expert Opin Investig Drugs 2000; 9: 2783-97.

26 Martins A, Vieira H, Gaspar H, Santos S. Marketed marine natural products in the pharmaceutical and cosmeceutical industries: tips for success. Mar Drugs 2014; 12: 1066-101.

27 Stevenson CS, Capper EA, Roshak AK, Marquez B, Eichman C, Jackson JR, et al. The identification and characterization of the marine natural product scytonemin as a novel antiproliferative pharmacophore. J Pharmacol Exp Ther 2002; 303: 858-66.

28 Zhang L, An R, Wang J, Sun N, Zhang S, Hu J, et al. Exploring novel bioactive compounds from marine microbes. Curr Opin Microbiol 2005; 8: 276-81.

29 Karthikeyan R, Somasundarama ST, Manivasagam T, Balasubramanian T, Anantharaman P. Hepatoprotective activity of brown alga Padina boergesenii against $\mathrm{CCl}_{4}$ induced oxidative damage in Wistar rats. Asian Pac J Trop Med 2010; 3: 696-701.

30 Bupesh G, Amutha C, Vasanth S, Manoharan N, Raja RS, Krishnamoorthy R, et al. Hepatoprotective efficacy of Hypnea muciformis ethanolic extract on $\mathrm{CCl}_{4}$ induced toxicity in rats. Braz Arch Biol Tech 2012; 55: 857-63.

31 Zhao X, Xue CH, Wang JF. Hepatoprotective activity of low molecular fucoidan oligosaccharides from Laminaria japonica in mice with liver injury. Acta Nutrimenta Sin 2003; 03: 286-9.

32 Hong SW, Lee HS, Jung KH, Lee H, Hong SS. Protective effect of fucoidan against acetaminophen-induced liver injury. Arch Pharm Res 2012; 35: 1099-105.

33 Esmat AY, Said MM, Soliman AA, El-Masry KS, Badiea EA. Bioactive compounds, antioxidant potential, and hepatoprotective activity of sea cucumber (Holothuria atra) against thioacetamide intoxication in rats. Nutrition 2013; 29: 258-67.

34 D'Orazio N, Gammone MA, Gemello E, De Girolamo M, Cusenza S, Riccioni G. Marine bioactives: pharmacological properties and potential applications against inflammatory diseases. Mar Drugs 2012; 10: 812-33. 
35 Makhmoor T, Naheed S, Shujaat S, Jalil S, Hayat S, Choudhary MI, et al. Hepatoprotection by chemical constituents of the marine brown alga Spatoglossum variabile: a relation to free radical scavenging potential. Pharm Biol 2013; 51: 383-90.

36 Pereira DM, Cheel J, Areche C, San-Martin A, Rovirosa J, Silva LR, et al. Anti-proliferative activity of meroditerpenoids isolated from the brown alga Stypopodium flabelliforme against several cancer cell lines. Mar Drugs 2011; 9: 852-62.

37 Breton JJ, Chabot-Fletcher MC. The natural product hymenialdisine inhibits interleukin-8 production in U937 cells by inhibition of nuclear factor-kappaB. J Pharmacol Exp Ther 1997; 282: 459-66.

38 Gressner AM, Weiskirchen R. Modern pathogenetic concepts of liver fibrosis suggest stellate cells and TGF-beta as major players and therapeutic targets. J Cell Mol Med 2006; 10: 76-99.

39 Sun T, Wang Q, Yu Z, Zhang Y, Guo Y, Chen K, et al. Hyrtiosal, a PTP1B inhibitor from the marine sponge Hyrtios erectus, shows extensive cellular effects on PI3K/AKT activation, glucose transport, and TGFbeta/Smad2 signaling. Chembiochem 2007; 8: 187-93.

40 De Bleser PJ, Xu G, Rombouts K, Rogiers V, Geerts A. Glutathione levels discriminate between oxidative stress and transforming growth factor-beta signaling in activated rat hepatic stellate cells. J Biol Chem 1999; 274: 33881-7.

41 Sakaida I, Matsumura Y, Akiyama S, Hayashi K, Ishige A, Okita K. Herbal medicine Sho-saiko-to (TJ-9) prevents liver fibrosis and enzyme-altered lesions in rat liver cirrhosis induced by a cholinedeficient L-amino acid-defined diet. J Hepatol 1998; 28: 298-306.

42 Lee JK, Kim JH, Shin HK. Therapeutic effects of the oriental herbal medicine Sho-saiko-to on liver cirrhosis and carcinoma. Hepatol Res 2011; 41: 825-37.

43 Vargas-Mendoza N, Madrigal-Santillan E, Morales-Gonzalez A, Esquivel-Soto J, Esquivel-Chirino C, Garcia-Luna Y, et al. Hepatoprotective effect of silymarin. World J Hepatol 2014; 6: 144-9.

44 Kelman D, Posner EK, McDermid KJ, Tabandera NK, Wright PR, Wright AD. Antioxidant activity of Hawaiian marine algae. Mar Drugs 2012; 10: 403-16.

45 Balaji Raghavendra Rao H, Sathivel A, Devaki T. Antihepatotoxic nature of Ulva reticulata (Chlorophyceae) on acetaminophen-induced hepatoxicity in experimental rats. J Med Food 2004; 7: 495-7.

46 Ngo DH, Vo TS, Ngo DN, Wijesekara I, Kim SK. Biological activities and potential health benefits of bioactive peptides derived from marine organisms. Int J Biol Macromol 2012; 51: 378-83.

47 Liu X, Sun Z, Zhang M, Meng X, Xia X, Yuan W, et al. Antioxidant and antihyperlipidemic activities of polysaccharides from sea cucumber Apostichopus japonicus. Carbohydr Polym 2012; 90: 1664-70.

48 Borkham-Kamphorst E, Kovalenko E, van Roeyen CR, Gassler N, Bomble M, Ostendorf $\mathrm{T}$, et al. Platelet-derived growth factor isoform expression in carbon tetrachloride-induced chronic liver injury. Lab Invest 2008; 88: 1090-100.

49 Nair DG, Miller KG, Lourenssen SR, Blennerhassett MG. Inflammatory cytokines promote growth of intestinal smooth muscle cells by induced expression of PDGF-Rbeta. J Cell Mol Med 2014; 18: 44454.

50 Choi BK, Cha BY, Yagyu T, Woo JT, Ojika M. Sponge-derived acetylenic alcohols, petrosiols, inhibit proliferation and migration of plateletderived growth factor (PDGF)-induced vascular smooth muscle cells. Bioorg Med Chem 2013; 21: 1804-10.

51 Pinchuk B, Johannes E, Gul S, Schlosser J, Schaechtele C, Totzke F, et al. Marine derived hamacanthins as lead for the development of novel PDGFRbeta protein kinase inhibitors. Mar Drugs 2013; 11: 3209-23.

52 Tong Y, Zhang X, Tian F, Yi Y, Xu Q, Li L, et al. Philinopside A, a novel marine-derived compound possessing dual anti-angiogenic and antitumor effects. Int J Cancer 2005; 114: 843-53.
53 Senni K, Pereira J, Gueniche F, Delbarre-Ladrat C, Sinquin C, Ratiskol $\mathrm{J}$, et al. Marine polysaccharides: a source of bioactive molecules for cell therapy and tissue engineering. Mar Drugs 2011; 9: 1664-81.

54 Dvir-Ginzberg M, Gamlieli-Bonshtein I, Agbaria R, Cohen S. Liver tissue engineering within alginate scaffolds: effects of cell-seeding density on hepatocyte viability, morphology, and function. Tissue Eng 2003; 9: 757-66.

55 Yan Y, Wanshun L, Baoqin H, Bing L, Chenwei F. Protective effects of chitosan oligosaccharide and its derivatives against carbon tetrachloride-induced liver damage in mice. Hepatol Res 2006; 35 : $176-84$

56 Subhapradha N, Saravanan R, Ramasamy P, Srinivasan A, Shanmugam V, Shanmugam A. Hepatoprotective effect of betachitosan from gladius of Sepioteuthis lessoniana against carbon tetrachloride-induced oxidative stress in Wistar rats. Appl Biochem Biotechnol 2014; 172: 9-20.

57 Ramasamy P, Subhapradha N, Shanmugam V, Shanmugam A. Protective effect of chitosan from Sepia kobiensis (Hoyle 1885) cuttlebone against $\mathrm{CCl}_{4}$ induced hepatic injury. Int J Biol Macromol 2014; 65: 559-63.

58 Gu Z, Dang TT, Ma M, Tang BC, Cheng H, Jiang S, et al. Glucoseresponsive microgels integrated with enzyme nanocapsules for closed-loop insulin delivery. ACS Nano 2013; 7: 6758-66.

59 Depner CM, Torres-Gonzalez M, Tripathy S, Milne G, Jump DB. Menhaden oil decreases high-fat diet-induced markers of hepatic damage, steatosis, inflammation, and fibrosis in obese $\mathrm{Ldlr}^{-/-}$mice. J Nutr 2012; 142: 1495-503.

60 Jump DB. N-3 polyunsaturated fatty acid regulation of hepatic gene transcription. Curr Opin Lipidol 2008; 19: 242-7.

61 Roy R, Chandrasekhar D, Pujari P. Dietary fish oil as hepatoprotective agent in Mus musculus. Indian J Exp Biol 2007; 45: 367-70.

62 Kikugawa K, Yasuhara Y, Ando K, Koyama K, Hiramoto K, Suzuki $M$. Protective effect of supplementation of fish oil with high $n-3$ polyunsaturated fatty acids against oxidative stress-induced DNA damage of rat liver in vivo. J Agric Food Chem 2003; 51: 6073-9.

63 Chen F, Liu Y, Zhu H, Hong Y, Wu Z, Hou Y, et al. Fish oil attenuates liver injury caused by LPS in weaned pigs associated with inhibition of $\mathrm{TLR}_{4}$ and nucleotide-binding oligomerization domain protein signaling pathways. Inn Immun 2013; 19: 504-15.

64 Naqshbandi A, Khan MW, Rizwan S, Yusufi ANK, Khan F. Studies on the protective effect of fish oil against cisplatin induced hepatotoxicity. Biol Med 2011; 3: 86-97.

65 Kalra J, Ali B, Kalra S, Pant KK. Fish oil and its role in acetaminophen induced hepatic injury. Asian J Exp Biol Sci 2012; 3: 826-9.

66 Mahmoud IY, Al-Musharafi SK, Al-Bahry SN, Al-Amri IS. Environmental changes and their effects on the fate of sea turtle reproductive potential and conservation. Biotechnology and conservation of species from arid regions. New York: Nova Science Publisher, Inc, USA, 2013; 13: 137-44.

67 Al-Jufaili SM, Hermosa G, Al-Shuaily SS, Al-Mujaini A. Oman fish biodiversity. J Facul Mar Sci 2010, 21: 3-51.

68 Elshafie AE, Al-Lawatia T, Al-Bahry S. Fungi associated with black tea and tea quality in the Sultanate of Oman. Mycopathologia 1999; 145: 89-93.

69 Elshafie AE, Al-Rashdi TA, Al-Bahry SN, Bakheit CS. Fungi and aflatoxins associated with spices in the Sultanate of Oman. Mycopathologia 2002; 155: 155-60.

70 El-Nagerabi SAF, AIBahry SN, Elshafie AE, Al-Hilali S. Effect of Hibiscus sabdariffa extract and Nigella sativa oil on the growth and aflatoxin $\mathrm{B}_{1}$ production of Aspergillusflavus and Aspergillusparasiticus strains. Food Control 2012, 25: 59-63.

71 El-Nagerabi SA, Elshafie AE, AlKhanjari SS, Al-Bahry SN, Elamin MR. The potential of baobab (Adansoniadigitata L) extracts as biocontrol 
on the growth and aflatoxin production by Aspergillus flavus and $A$ parasiticus. J Food Res 2013, 2: 93-103.

72 Sayed HA, El Ayyat A, El Dusoki H, Zoheiry M, Mohamed S, Hassan M, et al. A cross sectional study of hepatitis B, C, some trace elements, heavy metals, aflatoxin B1 and schistosomiasis in a rural population, Egypt. J Egypt Public Health Assoc 2005; 80: 355-88.

73 Al-Musharafi SK, Mahmoud IY, Al-Bahry SN. Heavy metal contamination from treated sewage effluents. 11th International conference on modelling, monitoring, and management of water pollution. WIT Transactions on Ecology and the Environment, New Forest. UK, Vol 164, 2012: 381-9.

74 Al-Musharafi SK, Mahmoud IY, Al-Bahry SN. Contamination of marine fish by heavy metals from coastal sewage treated effluent runoff. The third Asian conference on sustainability, energy and the environment. acsee2013. Osaka, Japan. The International Academic Forum (IAFOR), 2013: 100-7.

75 Al-Musharafi SK, Mahmoud, IY, Al-Bahry SN. Heavy metal pollution from treated sewage effluent. APCBEE Procedia 2013, 5: 344-8.

76 Al-Musharafi SK, Mahmoud IY, Al-Bahry SN. Heavy metals infiltration from sewage treated effluent into soil and tomato plants. IPCBEE 2013, 50: 16-25.

77 Al-Lawati TT, George M, Al-Lawati FA. Pattern of liver diseases in Oman. Ann Trop Paediatr 2009; 29: 183-9.

78 Proteau PJ, Gerwick WH, Garcia-Pichel F, Castenholz R. The structure of scytonemin, an ultraviolet sunscreen pigment from the sheaths of cyanobacteria. Experientia 1993; 49: 825-9.

79 Sanchez-Ferrando F, San-Martin A. Epitaondiol: The first polycyclic meroditerpenoid containing two fused six-membered rings forced into the twist-boat conformation. J Org Chem 1995; 60: 1475-78.

80 Fronczek FR, Caccamese S. Redetermination of pacifenol, a halogenated sequiterpene from the Mediterranean red alga Laurencia majuscula. Acta Cryst 1986, C42: 1649-51.

81 Gil B, Ferrandiz ML, Sanz MJ, Terencio MC, Ubeda A, Rovirosa J, SanMartin A, Alcaraz MJ, Paya M. Inhibition of inflammatory responses by epitaondiol and other marine natural products. Life Sci 1995; 57 : PL25-30.

82 Pereira DM, Cheel J, Areche C, San-Martin A, Rovirosa J, Silva LR, Valentao P, Andrade PB. Anti-proliferative activity of meroditerpenoids isolated from the brown alga Stypopodium flabelliforme against several cancer cell lines. Mar Drugs 2011; 9: 852-62.

83 Burgoyne DL, Andersen RJ, Allen TM. Contignasterol, a highly oxygenated steroid with the unnatural 14.beta configuration from the marine sponge Petrosia contignata Thiele, 1899. J Org Chem 1992; 57: 525-8.

84 Takei M, Burgoyne DL, Andersen RJ. Effect of contignasterol on histamine release induced by anti-immunoglobulin $E$ from rat peritoneal mast cells. J Pharm Sci 1994; 83: 1234-5.

85 Takei M, Umeyama A, Shoji N, Arihara S, Endo K. Mechanism of inhibition of IgE-dependent histamine release from rat mast cells by xestobergsterol A from the Okinawan marine sponge Xestospongia bergquistia. Experientia 1993; 49: 145-9.

86 Keyzers RA, Northcote PT, Webb V. Clathriol, a novel polyoxygenated 14 beta steroid isolated from the New Zealand marine sponge Clathria lissosclera. J Nat Prod 2002; 65: 598-600.

87 Takamatsu S, Hodges TW, Rajbhandari I, Gerwick WH, Hamann MT, Nagle DG. Marine natural products as novel antioxidant prototypes. J Nat Prod 2003; 66: 605-8.

88 de Oliveira e Silva AM, Vidal-Novoa A, Batista-Gonzalez AE, Pinto $\mathrm{JR}$, Portari Mancini DA, Reina-Urquijo W, et al. In vivo and in vitro antioxidant activity and hepatoprotective properties of polyphenols from Halimeda opuntia (Linnaeus) Lamouroux. Redox Rep 2012; 17: 47-53.
89 Yeh YH, Hsieh YL, Lee YT, Hu CC. Protective effects of Geloina eros extract against carbon tetrachloride-induced hepatotoxicity in rats. Food Res International 2012; 48: 551-8.

90 He X, Cao W, Zhao Z, Zhang C. Analysis of protein composition and antioxidant activity of hydolysates from Paphia undulate. J Food Nutrition Res 2013; 1: 30-6.

91 Althunibat OY, Ridzwan BH, Taher M, Daud JM, Jauhari Arief Ichwan $\mathrm{S}$, Qaralleh H. Antioxidant and cytotoxic properties of two sea cucumbers, Holothuria edulis lesson and Stichopus horrens Selenka. Acta Biol Hung 2013; 64: 10-20.

92 Antioxidant peptides isolated from sea cucumber Stichopus Japonicus. Eur Food Res Technol 2012; 234: 441-7.

93 Hong SW, Lee HS, Jung KH, Lee H, Hong SS. Protective effect of fucoidan against acetaminophen-induced liver injury. Arch Pharm Res 2012; 35: 1099-1105.

94 Liaw CC, Lin YC, Lin YS, Chen CH, Hwang TL, Shen YC. Four new briarane diterpenoids from Taiwanese gorgonian Junceella fragilis. Mar Drugs 2013; 11: 2042-53.

95 Badiu DL, Luque R, Dumitrescu E, Craciun A, Dinca D. Amino acids from Mytilus galloprovincialis (L) and Rapana venosa molluscs accelerate skin wounds healing via enhancement of dermal and epidermal neoformation. Protein J 2010; 29: 81-92.

96 Whitehouse MW, Fairlie DP. Anti-Inflammatory activity of a holothurian (sea cucumber) food supplement in rats. Inflammo Pharmacology 1994; 2: 411-417.

97 Kossuga MH, Nascimento AM, Reimão JQ, Tempone AG, Taniwaki NN, Veloso K, et al. Antiparasitic, antineuroinflammatory, and cytotoxic polyketides from the marine sponge Plakortis angulospiculatus collected in Brazil. J Nat Prod 2008; 71: 334-9.

98 Kobayashia H, Kitamurab K, Nagaic K, Nakaoa Y, Fusetania N, van Soestd RWM, et al. Carteramine A, an inhibitor of neutrophil chemotaxis, from the marine sponge Stylissa carteri. Tetrahedron Lett 2007; 48: 2127-9.

99 Ku CS, Pham TX, Park Y, Kim B, Shin MS, Kang I, Lee J. Edible bluegreen algae reduce the production of pro-inflammatory cytokines by inhibiting NF-KB pathway in macrophages and splenocytes. Biochim Biophys Acta 2013; 30: 2981-8.

100 Huang X, Li M, Xu B, Zhu X, Deng Z, Lin W. Proteasome and NFkappa $B$ inhibiting phaeophytins from the green alga Cladophora fascicularis. Molecules 2007; 12: 582-92.

101 Posadas I, De Rosa S, Terencio MC, Paya M, Alcaraz MJ. Cacospongionolide $B$ suppresses the expression of inflammatory enzymes and tumour necrosis factor-alpha by inhibiting nuclear factor-kappa $B$ activation. Br J Pharmacol 2003; 138: 1571-9.

102 Nagle DG, Zhou YD, Mora FD, Mohammed KA, Kim YP. Mechanism targeted discovery of antitumor marine natural products. Curr Med Chem 2004;11: 1725-56.

103 Catassi A, Cesario A, Arzani D, Menichini P, Alama A, Bruzzo C, et al. Characterization of apoptosis induced by marine natural products in non small cell lung cancer A549 cells. Cell Mol Life Sci 2006; 63: 2377-86.

104 Kang KH, Qian ZJ, Ryu B, Karadeniz F, Kim D, Kim SK. Hepatic fibrosis inhibitory effect of peptides isolated from navicula incerta on TGF- $\beta 1$ Induced activation of LX-2 human hepatic stellate cells. Prev Nutr Food Sci 2013; 18: 124-32.

105 Chao CH, Wen ZH, Wu YC, Yeh HC, Sheu JH. Cytotoxic and antiinflammatory cembranoids from the soft coral Lobophytum crassum. J Nat Prod 2008; 11: 1819-24.

106 Cheng SY, Wen ZH, Chiou SF, Hsu CH, Wang SK, Dai CF, et al. Durumolides A-E, anti-inflammatory and antibacterial cembranolides from the soft coral Lobophytum durum. Tetrahedron 2008; 64: 9698-704. 